\title{
The Role of Wetlands for Climate Change Mitigation and Biodiversity Conservation
}

\author{
1,2DINSA, TT ; ${ }^{2}$ GEMEDA, DO
}

\author{
${ }^{1}$ Hunde Oromo Grass Root Development Initiative, Jimma Agro Biodiversity, Jimma, Ethiopia \\ ${ }^{2}$ Jimma University College of Agriculture and Veterinary Medicine, Department of Natural Resources Management, Jimma, Ethiopia. \\ *Corresponding Author Email: dessalegn.obsi@ju.edu.et; dasoobsi@gmail.com; Tel: +251-917-85-23-22
}

\begin{abstract}
Wetland is crucial in supporting biodiversity conservation and climate change regulation. A wetland ecosystem has been influenced by anthropogenic driven climate change. The main objective of this paper is to analyze the role of wetlands for climate change mitigation and biodiversity conservation through literature review. Wetland is vulnerable to climate change through alterations of hydrological regimes that lead to changes in quantity and quality of water. Climate change is undoubtedly the most pervasive, complex and challenging of the global environmental issues facing contemporary society and it affects all aspects of development. Wetlands play a key role in hydrological and biogeochemical cycles, and provide a wide range of ecosystem goods and services to humankind. In spite of these facts, wetlands are considered as wastelands in the past, which contributes for deterioration of wetlands in several places. Thus, strong environmental policy is required for the conservation of wetland ecosystem.
\end{abstract}

\section{DOI:https://dx.doi.org/10.4314/jasem.v23i7.16}

Copyright: Copyright $\left({ }_{0} 2019\right.$ Dinsa and Gemeda. This is an open access article distributed under the Creative Commons Attribution License (CCL), which permits unrestricted use, distribution, and reproduction in any medium, provided the original work is properly cited.

Dates: Received: 19 March 2019; Revised: 10 June 2019; Accepted 16 July 2019

Keywords: carbon sequestration, climate change, climate change mitigation, biodiversity conservation, wetlands

Wetlands play a key role in hydrological and biogeochemical cycles, and provide a wide range of ecosystem goods and services to humankind. Wetland has the capacity to retain water during dry season and keeping the water table high and moderately stable (Orimoloye et al., 2018). It has a potential to regulate a microclimate (Simsek and Odul, 2018). Wetlands provide many ecosystem services that are critical to reduce the vulnerability of communities to climate change in general and to extreme weather events in particular. Wetland has a fundamental ecological function that plays an irreplaceable role in serving biological survival and human development (Chen et al., 2019). The total carbon stock in wetlands was more than double as compared to converted cultivated as well as grazing lands (Kassa et al., 2015). Climate change, sediment condition differences and human activities like agricultural practices, built up and deforestation are the major causes of wetland deterioration (Orimoloye et al., 2018). Lee et al. (2018) justify that wetland function has mostly limited to individual wetlands and overall catchment functions have rarely been investigated.

Globally wetland ecosystems are under threats due to change in water regimes as a result of river regulation and climate change (Fu et al., 2015). Global climate change is recognized as one of the key drivers of degradation of wetland ecosystems, causing considerable change of services provided by these habitats (Mehvar et al., 2019). Expanding agriculture leads to habitat loss and fragmentation, drainage of wetlands, and impacts on freshwater and marine ecosystems through sedimentation and pollution and is one of the greatest threats to biodiversity worldwide (World Bank, 2008). This study is aimed to review the role of wetlands for climate change mitigation and its potential in biodiversity conservation.

\section{MATERIALS AND METHODS}

This research work was conducted through scientific literature review. Various databases, Google scholar, Science direct, and Google web based search were used to review the role of wetland for climate change and biodiversity conservation. Finally, 23 most documents were selected for this review paper.

\section{RESULTS AND DISCUSSION}

Wetlands and Climate Change: Wetlands are among the most important natural resources on earth that provide a potential sink for atmospheric carbon but-if not managed properly, they become a source of greenhouse gases (Adhikari et al., 2009). Wetlands are an important carbon sink, contributing for climate regulation (Villa and Bernal, 2018). Wetland systems worldwide have been influenced by anthropogenic change (Shand et al., 2017). Wetlands are vulnerable to human-induced climate change (House et al., 2016) but, if managed well, their ecosystems and 
biodiversity play a key role in the mitigation and adaptation of climate change and will be important in helping humans to adapt to climate change through their critical role in ensuring water and food security. Thus, it is sound to work on wetland restoration management, which is an important tool for stakeholders and practitioners to mitigate climate change and maintain ecological functioning (Dorau et al., 2015). Wetland ecosystems are essential for climate change mitigation. Water and wellfunctioning wetlands play a key role in responding to climate change and in regulating natural climatic processes (through the water cycle, maintenance of biodiversity, reduced GHG emissions, and buffering of impacts). Conservation and wise use of wetlands help to reduce the negative economic, social and ecological effects (Ramsar, 2009).

Wetlands store higher carbon content relative to other terrestrial ecosystems (Naidoo et al., 2019), they can function as either greenhouse gas sinks or sources depending on their type, their use and ambient conditions. Some wetlands are characteristically sources and others are sinks. Some have a different role at different times as determined by hydrology. Carbon sinks are ecosystems (the main ones being soil, oceans and forests) that store $\mathrm{CO}_{2}$ in water, sediment, wood, roots, leaves and the soil.

Wetland Carbon Stocks: Wetlands cover $6 \%$ of the world's land surface but contain $14 \%$ of the terrestrial biosphere carbon pool. There is a significant amount of carbon stored in wetland soils, peats, litter, and vegetation (globally estimated 500-700GT).The amount stored in wetlands may approach the total amount of atmospheric carbon (estimated at 753GT) (IPCC,2002). Of various wetland types, peat land has been recognized worldwide as highly important for carbon storage since it accounts for nearly $50 \%$ of the terrestrial carbon storage with only $3 \%$ cover of world's land areal. Peat lands contain the most carbon (Guo and Gifford, 2002; Multiby and Immirz, 1993). The terrestrial biosphere is estimated to contain a carbon pool of $1943 \mathrm{Gt}$. Wetlands constitute a large global $\mathrm{C}$ reservoir at $230 \mathrm{Gt}$, exceeding agroecosystems $(150 \mathrm{Gt})$ and temperate forests (159 $\mathrm{Gt})$. Tropical wetlands store $80 \%$ more carbon than temperate wetlands (Bernal, 2008).

Wetlands play an important role in the regulation of global climate in two ways: through mitigation and adaptation. Mitigation, through reducing GHG emissions, largely concerns the protection and promotion of carbon sinks, through land-use and habitat management and also involves the encouragement of the use of non-carbon or carbon- neutral energy sources, and the improvement of energy efficiency (Berry et al., 2009). IPCC(2002) defined mitigation as an anthropogenic intervention to reduce net greenhouse gas emissions that would lessen the pressure on natural and human systems from climate change. Wetland ecosystems (including peat lands) also represent important natural carbon stores, and their restoration must be an essential component in climate change mitigation strategies. Based on these findings, the IPCC has subsequently concluded that the "restoration of drained and degraded peat lands is one of the key low-cost greenhouse gases mitigation strategies." Due to the rapid rate of vegetative growth and improved hydrology, wetland restoration is perhaps the most efficient (low-cost) method for sequestering carbon and reducing emissions in the short term (Bernal, 2008).

Required Actions for Improving Wetlands Conservation: Conservation of wetlands is a relatively recent priority, and it has seen more recent shifts from protection of remaining wetlands initially as a static biodiversity resource towards a focus on the many, formerly largely undervalued beneficial functions that these ecosystems provide to society (Maltby et al., 2013). Policymakers have sufficient scientific information to understand the urgent need to take appropriate actions to conserve wetlands and their services to people (Gardner et al., 2015). In order to reverse emerging problems and conserve these fragile but crucial wetlands, integrated problem solving approach through realizing the collaboration of relevant stakeholders from policy level down to grassroots community who have stake in wetlands should cooperate and contribute their part. Decision makers at higher levels are required to strengthen sustainable wetland management efforts through effecting policy and legislation, improving institutional arrangements and supporting capacity building initiatives.

Conclusions: Wetland played a crucial role in climate change mitigation and biodiversity conservation. Wetlands are among the world's most importantassets, providing the basis for human survival and development. Wetland has the potential to stabilize microclimates, retain and purify agrochemicals, toxicants and sediments; minimize the occurrence of drought and floods; and recharge ground water. However, because of over utilization, missunderstanding as well as lack of awareness from the public about the use of wetlands, wetlands are under threat. The over utilization of wetlands directly affects biodiversity conservation. For instance, study conducted in Ethiopia by Gemeda et al. (2016) confirmed that the local communities are converting 
wetlands for agricultural purpose which threatened the life of Black Crowned crane. Thus, proper management of wetlands is required from various sectors and organization.

Acknowledgements:We would like to acknowledge our institutes Jimma University College of Agriculture and Veterinary Medicine for the existing facilities to conduct this review paper.

\section{REFERENCES}

Adhikari, S; Bajracharaya, RM; Sitaula, BK (2009). Review Paper: A Review of Carbon Dynamics and Sequestration in Wetlands. J. Wetlands Ecol. (2):42.46.

Bernal, B (2008). Carbon pools and profiles in wetland soils: The effect of climate and wetland type. M.Sc. thesis, presented in partial fulfillment of the requirements for Master's degree in the Graduate School of the Ohio State University.

Berry, P; Paterson, JS; Cabeza, M; Dubuis, A; Guisan, A; Jaattela, L; Kuhn, I; Musche, M; Piper, J; Wilson, E (2009). Climate Change Adaptation and Mitigation: Synergisms and Trade-offs for Biodiversity. IOP Conf. Series: Earth and Environmental Science, 6 (31) 2002. IOP Publishing Ltd.

Chen, W; Cao, C; Liu, D; Tian, R; Wu, C; Wang, Y; Qian, Y; Ma, G; Bao, D (2019). An evaluating system for wetland ecological health: Case study on nineteen major wetlands in Beijing-TianjinHebei region, China. Sci. Total Environ. 666:10801088.

Dorau, K; Gelhausen, H; Esplor, D; Manseldt, T (2015). Wetland restoration management under the aspect of climate change at a mesotrophic fen in Northern Germany. Ecol. Engineer. 84:84-91.

Fu, B; Pollino, C.A; Cuddy, SM; Andrews, F (2015). Assessing climate change impacts on wetlands in a flow regulated catchment: A case study in the Macquarie Marshes, Australia. J. Environ. Manage. 157: 127-138.

Gardner, RC; Barchiesi, S; Beltrame, C; Finlayson, CM; Galewski, T; Harrison, I; Paganini, M; Perennou, C; Pritchard, DE; Rosenqvist, A; Walpole, M (2015). State of the World's Wetlands and their Services to People: A compilation of recent analyses. Ramsar Briefing Note, no. 7(June), 1-20.
Gemeda, DO; Minstro, AA; Feyssa, DH; Sima, AD; Gutema, TM. 2016. Community knowledge, attitude and practice towards black crowned crane (Balearica pavonina L.) conservation in Chora Boter district of Jimma Zone, Ethiopia. J. Ecol. Nat. l Environ. 8 (4):40-48.

Gulbin, S; Kirilenko, AP; Kharel, G; Zhang, X (2019). Wetland loss impact on long term flood risks in a closed watershed. Environmental Science \& Policy, 94:112-122.

Guo, LB; Gifford, RM (2002).Soil Organic Stocks and Land Use Change: A MetaAnalysis. Global Change Biology, 8,345-360

House, AR; Thompson, JR; Acreman, MC (2016). Projecting impacts of climate change on hydrological conditions and biotic responses in a chalk valley riparian wetland. J. Hydrolog. 534: 178-192.

IPCC, (2002). Climate Change and Biodiversity. IPCC Technical Paper V. IPCC, 2007: Mitigation of Climate Change.

Kassa, YA; Anteneh, BH; Teshome, TT (2015). Effect of Wetland Degradation and Conversion on Carbon Stock: The Case of Tekuma Wetland, Lake Tana Sub-Basin, 3(2), 121-133.

Lee, S; Yeo, IY; Lang, MW; Sadeghi, AM; McCarty, GW; Moglen, GE; Evenson, GR (2018). Assessing the cumulative impacts of geographically isolated wetlands on watershed hydrology using the SWAT model coupled with improved wetland modules. $J$. Environ. Manage. 223 (1):37-48.

Maltby, E; Immirzi, P (1993). Carbon dynamics in peat lands and the other wetlands soils: regional and global perspectives. Chemosphere, 27: 9991023.

Maltby, E; Acreman, M; Blackwell, MSA; Everard, M; Morris, J (2013). The Challenges and Implications of Linking Wetland Science to Policy in Agricultural Landscapes - Experience from the UK National Ecosystem Assessment. Ecol. Engineer. 56, 121-133.

Mehvar, S; Filatova, T; Sarker, MH; Dastgheib, A; Ranasinghe, R (2019). Climate change-driven losses in ecosystem services of coastal wetlands: A case study in the West coast of Bangladesh. Ocean \& Coast. Manage. 169: 273-283. 
Naidoo, L.; Deventer, H; Ramoelo, A; Mathieu, R; Nondlazi, B; Gangat, R (2019). Estimating above ground biomass as an indicator of carbon storage in vegetated wetlands of the grassland biome of South Africa. Inter. J. Appl. Earth Observe. Geoinformat. 78: 118-129.

Orimoloye, IR; Kalumba, AM; Mazinyo, SP; Nel, W (2018). Geospatial analysis of wetland dynamics: Wetland depletion and biodiversity conservation of Isimangaliso Wetland, South Africa. J. King Saud Univ. Sci. . https:// doi.org/ 10.1016/ j.jksus. 2018.03. 004 (in press).

Ramsar Scientific \& Technical Review Panel (STRP), (2009). Wetlands and the UNFCCC COP15 climate Change meeting (Copenhagen, 7-18, December 2009) Ramsar, 1998. About the Ramsar Convention on Wetlands.
Shand, P; Grocke, S; Creeper, NL; Baker, AK; Fitzpatrick, RW; Love, A.J (2017). Impacts of climate change, climate variability and management on soil and water quality in wetlands of South Australia. Procedia Earth and Planetary Science, 17: $456-459$.

Simsek, CK; Odul, H (2018). Investigation of the effects of wetlands on micro-climate. Appl. Geog. 97:48-60.

Villa, JA; Bernal, B (2018). Carbon sequestration in wetlands, from science to practice: An overview of the biogeochemical process, measurement methods, and policy framework. Ecol. Engineer. 114:115-128.

World Bank, (2008).Biodiversity, Climate Change and Adaptation: Nature-Based Solutions from the World Bank Portfolio. Washington, DC 20433 USA. 